UDC 613.644: 613.6.02: 665.71

DOI: $10.21668 /$ health.risk/2017.1.13.eng

\title{
IN-PLANT NOISE AS OCCUPATIONAL RISK FACTOR AT PETROCHEMICAL PLANTS
}

\author{
A.D. Volgareva ${ }^{1}$, L.K. Karimova ${ }^{1}$, L.N. Mavrina $^{1}$, Z.F. Gimaeva ${ }^{1,2}$, N.A. Beigul ${ }^{1}$ \\ ${ }^{1}$ Ufa Research Institute of Occupational Health and Human Ecology, 94 Stepana Kuvykina Str., \\ Ufa, 450106, Russian Federation \\ ${ }^{2}$ Bashkirian State Medical University, 3 Lenina Str., Ufa, 450000, Russian Federation
}

The article summarizes the data obtained in long-term research on working conditions estimates and studying damages to hearing organs in workers employed at petrochemical plants. We chose workers employed at five basic organic synthesis productions as an object of our study; these productions include ethylene-propylene, ethylbenzene-styrene, organic alcohols production (butanol and 2-ethylhexanol), phthalic anhydride.

We detected that heating furnaces, compressors, and pumps were the main noise sources at the examined productions. Our research revealed that noise levels at the examined productions varied from 60 to 99 decibel, and calculated equivalent noise levels reached the 3 hazard class with 1st and 2 nd hazard degree.

Audiometric research showed that signs of impacts exerted by noise on hearing organs of workers belonging to basic occupational groups (processing machine operators and pumps and compressor operators) occurred authentically more frequently than in case of control equipment mechanics and automatic equipment operators (comparison group) (<0,001). The highest risk of occupational hearing loss was detected for drivers while the same pathology evolved 1.5-2.0 times less frequently in processing machines operators. Frequency of hearing organs damage in all basic occupational groups authentically increased as working period grew. Signs of such damage increased dramatically in processing machines operators' group after 10 years of work but still the overall level was slightly lower than in drivers' group.

It is shown that the most efficient measures of collective protection aimed at noise reduction are application of low-noise technological equipment, acoustic protection (sound insulation and sound absorption, etc), remote control, as well as rational labor and leisure regime. Medical care and vocational rehabilitation of people with occupational hearing loss also contribute significantly into sensory deafness prevention.

Key words: in-plant noise, working conditions, occupational risk, petrochemical productions, signs of impacts exerted by noise on hearing organs, organic synthesis, вpedнble u hazardous factors, occupational pathology.

Occupational disease of a hearing organ is a eases in economically developed countries. vital problem all over the world $[19,21,24]$. As per World Health Organization data, sensory hearing loss of noise etiology has been constantly leading among other occupational dis

However, it has recently tended to go down as national programs aimed at protection from noise have been implemented [17,23].

In Russia in-plant noise is also one of the

(C) Volgareva A.D., Karimova L.K., Mavrina L.N., Gimaeva Z.F., Beigul N.A., 2017

Al'fiya D. Volgareva - Candidate of Medical Sciences, otorhinolaryngologist (e-mail: iao_karimova@rambler.ru; tel.: +7 (347) 255-57-21).

Liliya K. Karimova - Doctor of medical sciences, professor; Chief Researcher of the Department of Occupational Hygiene and Physiology (e-mail: iao_karimova@rambler.ru; tel.: +7 (347) 255-57-21).

Liana N. Mavrina - Candidate of Biological Sciences; Senior Researcher of the Department of Occupational Hygiene and Physiology (e-mail: Liana-1981@ mail.ru; tel.: +7 (347) 255-57-21).

Zul'fiya F. Gimaeva - Candidate of medical sciences, Senior Researcher of the Department of Occupational Health Care (e-mail: gzf-33@mail.ru; tel.: +7 (347) 255-30-57).

Natalya A. Beygul - Candidate of chemical sciences, Associate Professor; Senior Researcher of the Department of Occupational Hygiene and Physiology (e-mail: iao_karimova@rambler.ru; tel.: +7 (347) 255-57-21). 
leading adverse factors at working places in most industries. Nowadays occupational hearing loss becomes more significant, socially and economically $[1,4,6,16]$. As per Rospotrebnadzor data, one third of workers undergo in-plant noise impacts these days. It determines a growth in occupational hearing loss levels, especially in the structure of diseases related to physical factors impacts [10].

Sensory hearing loss is one of the prevailing diseases in overall occupational morbidity structure. Its specific weight has doubled over the last decade (from $13.5 \%$ to $27.2 \%$ ). Its specific weight is even higher among diseases caused by impacts which physical factors of working environment exert on workers $(59 \%)[10,13,15]$.

It is well known that if noise impact on a human body is long-term, it leads to auditory analyzer fatigue which can result in persistent hearing loss if there is no sufficient rest $[3,20]$. Auditory analyzer examining with the use of pure tone audiometry is an important diagnostic technique aimed at detecting signs of specific impacts exerted by in-plant noise on a hearing organ $[2,14]$.

Petrochemical industry belongs to such branches where in-plant noise is one of adverse working environment factors, together with air pollution in working areas and unfavorable microclimate $[7,8,18,22,25]$.

More and more powerful equipment has been applied in petrochemical industry recently, and it has resulted in more intense in-plant noise at working places $[5,8,20]$.

Our research goal was to assess probability of occupational hearing organs disorders in workers employed at contemporary petrochemical production basing on dose assessment of in-plant noise.

Data and methods. We chose five petrochemical productions as our research object; they were ethylene-propylene production, ethylbenzene-styrene production (old one with small capacity and modern one with large capacity), organic alcohols production (butanol and 2-ethylhexanol), phthalic anhydride production.
All hygienic research at the examined productions was accomplished in accordance with the current standard-methodological documents, namely: State Standard 12.1.005-88, Hygienic Standard 2.2.5.1313-03, Sanitary Standard 2.2.4/2.1.8.562-96, Sanitary Rules and Standards 2.2.548-96, P.2.2.2006-05.

We assessed hearing organs state in 1,597 workers whose occupations were processing equipment operators, pumps and compressors operators, supervisory instruments and automatic equipment (SI and $\mathrm{AE}$ ) mechanics.

In order to determine qualitative and quantitative features of hearing function we performed pure tone threshold audiometry in $125-8000 \mathrm{~Hz}$ frequency range as per air and bone sound conduction and sound perception according to conventional technique with the use of Interacoustics AD229e audiometer [9,12].

Results and discussion. Technological processes at organic synthesis production are continuous and are controlled remotely. Most technological equipment such as reactors, rectifying columns, tanks, reservoirs, industrial pipelines, separators, heat exchange units, furnaces etc., is placed outside workshops on outdoor grounds. The only exception is pumps and compressors which are placed inside workshops.

Most intense noise at the examined productions occurs due to heating furnaces, compressors, pumps, air cooling condensers as well as compressed air moving in the systems of secondary supervisory instruments and automation equipment.

In-plant noise existing at the examined productions is constant, broadband, with sound level prevalence for certain equipment both at high and low frequencies. Sound volumes depend on equipment type, power, capacity, its functioning regime, on a way in which it is erected on its base and on its connection to pipelines.

Comparative characteristics of in-plant noise intensity at the examined productions didn't reveal any specific discrepancies between them. Rank distribution of the equipment as per level of noise it generates revealed that heating 
furnaces were the noisiest, compressors and pumps followed (Table 1).

Table 1

Average data on in-plant noise at organic synthesis productions

\begin{tabular}{|l|c|c|}
\hline \multicolumn{1}{|c|}{ Place of measuring } & $\begin{array}{c}\text { Sound vol- } \\
\text { ume, dBA }\end{array}$ & $\begin{array}{c}\text { Higher } \\
\text { than } \\
\text { MPV, } \\
\text { dBA }\end{array}$ \\
\hline Heating furnaces & $95-99$ & Ha 15-19 \\
\hline Compressor houses & $92-96$ & Ha 12-16 \\
\hline Pump chambers & $85-94$ & Ha 5-14 \\
\hline Outdoor plants & $80-85$ & Ha 5 \\
\hline Soundproofing cabins & $60-63$ & - \\
\hline Operator rooms & $58-60$ & - \\
\hline
\end{tabular}

$\mathrm{N}$ o t e: MPV is maximum permissible volume; $\mathrm{dBA}$ is corrected sound power volume

Sound volumes produced by heating furnaces reached up to 95-99 dBA which was 1519 dBA higher than maximum permissible volume (MPV) with maximum sound energy being at $25-500 \mathrm{~Hz}$ frequencies.

Noise in compressor houses was 12-16 dBA higher than MPV, mostly at lower frequencies. Noise in pump chambers was constant, broadband and with high frequency. Its volumes fluctuated within wide range from 85 to $94 \mathrm{dBA}$ depending on a pump type, its capacity and functioning regime.

Noise volumes at outdoor plants amounted to $80-85 \mathrm{dBA}$ and it was $5 \mathrm{dBA}$ higher than MPV. Noise volumes in soundproofing cabins and in closed compressor houses were within 60$63 \mathrm{dBA}$. Noise volumes in operator rooms also didn't exceed MPV and were equal to 58-60 dBA.

Organic synthesis production involves shift work; each shift crew usually consists of processing equipment operators, pumps and compressors operators, and SI and AE mechanics. Technological process at the examined production was a continuous one and therefore working regime included three 8-hour shifts, one shift being a night one.

Processing equipment operators as per their job description had to manage technological process parameters which were shown either on computer screens or control panels in operator rooms. Besides, processing equipment operators controlled the state of the equipment and communications located both on outdoor plants and inside workshops. According to timing research a processing equipment operator spent approximately a half of his work shift in an operator room. Our research results revealed that noise volumes in operator rooms were considerably lower than MPV. Processing equipment operators had to perform maintenance inspection of technological equipment so they periodically left operator rooms up to 6 times a shift ( $20 \%$ of total shift time) and went directly to the equipment which was located both in workshops and on outdoor grounds. As per accomplished timing research processing equipment operators worked under intense noise conditions up to $50 \%$ of total shift time.

Technological process in up-to-date ethylbenzene-styrene production is continuous, its control is fully automated, and all technological operations are automatically managed so manual labor is totally excluded. Time period which workers have to spend in close proximity to technological equipment has decreased considerably due to complex mechanization and automation and it makes workers' exposure to adverse production factors less probable.

Workers at the examined production sometimes had to be near outdoor plants when a visual inspection or minor repair was required. Processing equipment operators left operator rooms to perform a maintenance inspection of the equipment and it happened 2 or 3 times a shift and took about $10 \%$ of total shift time. Calculated equivalent noise volume allowing for the time spent directly at "noise-making" equipment at the up-to-date production didn't exceed MPV and amounted to 75-78 dBA.

Calculated equivalent noise volumes for processing equipment operators employed at ethylene-propylene production amounted to 85$88 \mathrm{dBA}$ and corresponded to the 3rd class with the 2nd hazard and danger category; they amounted to 83-85 dBA at ethylbenzene-styrene production with small capacity which corresponded to 3.1 hazard and danger class. Equivalent noise volumes at phthalic anhydride production didn't exceed any hygienic standards 
and corresponded to the acceptable class 2 (table 2).

A group of pumps and compressors operators was the second in number (about 20\% of all workers). Their job responsibilities included maintenance inspections and control over technological pumps and compressors functioning. As per timing data pumps and compressors operators spent up to $70-80 \%$ of their total shift time near technological equipment. They also could perform minor and routine repair. Pumps and compressors operators employed at up-to-date ethylbenzene-styrene production spent from 30 to $50 \%$ of their total shift time inside pumping and compressor units. They also spent about $10-20 \%$ of their total shift time in operator rooms and soundproofing cabins where they made records in logs, spoke on the phone and discussed various production issues.

Pumps and compressors operators were under noise exposure during $70 \%$ of their total shift time and as a rule that noise volumes were 12-16 dBA higher than MPV. Allowing for the exposure time we can determine equivalent noise volumes at working places of pumps and compressors operators as having adverse working conditions of 3.2 hazard and danger class.

We should note that in spite of high in-plant noise volumes registered at production with large capacity, calculated equivalent noise volume for pumps and compressors operators allowing for the time spent directly at "noise-making equipment" was $5 \mathrm{dBA}$ higher than MPV which corresponded to 3.1. hazard and danger class (table 2).

The next occupational group in petrochemical production was $\mathrm{SI}$ and $\mathrm{AE}$ mechanics. They were responsible for maintenance of both "primary" devices (thermometers, flowmeters, pressure gauges) placed directly at equipment and "secondary" ones with their readings displayed on control panels.

SI and AE mechanics spent about 12.3$15.5 \%$ of their total shift time on "primary" devices maintenance and about $70-75 \%$, on "secondary" ones. Supervisory instruments in contemporary computerized manufacturing have rather complicated design, therefore mechanics are to be highly qualified. They performed maintenance inspections, routine repair and devices taring, filled up ink into recorders, replaced diagrams etc., in operator rooms. As for outdoor plants, there mechanics replaced pads in devices and columns in chromatographs which registered quality of products in flows. SI and $\mathrm{AE}$ mechanics underwent production factors impacts at levels which were considerably lower than permissible levels during $85 \%$ of their work shift. Calculated equivalent noise volume was considerable lower than permissible one.

\section{Table 2}

Working conditions assessment in terms of intensity of noise impacts exerted on workers employed at organic synthesis production

\begin{tabular}{|l|c|c|}
\hline \multirow{2}{*}{ Production } & \multicolumn{2}{|c|}{$\begin{array}{c}\text { Working conditions class in } \\
\text { terms of noise impacts intensity }\end{array}$} \\
\cline { 2 - 3 } & $\begin{array}{c}\text { Processing } \\
\text { equipment } \\
\text { operators }\end{array}$ & $\begin{array}{c}\text { Pumps and } \\
\text { compressors } \\
\text { operators }\end{array}$ \\
\hline $\begin{array}{l}\text { Ethylene- } \\
\text { propylene }\end{array}$ & 3.2 & 3.2 \\
\hline $\begin{array}{l}\text { Ethylbenzene- } \\
\text { styrene (small } \\
\text { capacity) }\end{array}$ & 3.1 & 3.2 \\
\hline $\begin{array}{l}\text { Ethylbenzene- } \\
\text { styrene (small } \\
\text { capacity)large }\end{array}$ & 2 & 3.1 \\
\hline $\begin{array}{l}\text { Alcohols (buta- } \\
\text { nol and 2- } \\
\text { ethylhexanol) }\end{array}$ & 3.1 & 3.2 \\
\hline $\begin{array}{l}\text { Phthalic anhy- } \\
\text { dride }\end{array}$ & 2 & 3.2 \\
\hline
\end{tabular}

High levels of noise impact make hearing loss evolvement in workers quite probable. Occupational hearing loss parameter is equal to $3,2 \%$ per 10,000 workers.

As we examined hearing organs of workers employed at petrochemical production we thought it advisable to highlight a group with so called pre-clinic form of occupational damage which we called "people with signs of noise impact on hearing organs" [2,11].

313 people employed at petrochemical production $(19.6 \pm 1.0 \%$ of total number of 
workers exposed to in-plant noise) had signs of noise impact on hearing organs.

Signs of noise impacts on hearing organs were most frequently detected in pumps and compressors operators in comparison with other basic occupational groups $(24.7 \pm 1.6 \%)$; processing equipment operators followed $(15.7 \pm 1.4 \%)$.

We detected statistically significant discrepancies in frequency with which noise impacts on hearing organs occurred in basic occupational groups in comparison with SI and AE mechanics. However, the most apparent discrepancies were detected in pumps and compressors operators as the analyzed parameter in them had authentic discrepancies even when their working period was less than 10 years $(p<0.001)$, and they became more and more persistent as their working period grew.

Statistically authentic discrepancies in processing equipment operators groups were detected only after 10 years of work $(\mathrm{p}<0.001)$. And as their working period under noise exposure grew, discrepancies became statistically more and more significant.

Dynamics related to working period and describing frequency with which signs of noise impacts on hearing organs occurred is given in Table 3.

As we can see from the given data, generally there are common trends in all the groups. However, it is obvious that noise impacts prevalence among pumps and compressors operators even with rather short working period is substantially higher than in other groups and this trend remains during the whole analyzed working period.

More drastic growth in signs frequency among processing equipment operators is observed after 10 years of work although the total parameter level remains a bit lower than in pumps and compressors operators.

Such dynamics (signs growth) is almost completely absent in SI and $\mathrm{AE}$ mechanics occupational group (taken as a control one).

Table 4 gives values of relative risks causing occurrence of signs showing noise impacts on hearing organs in occupational groups. The given data show that relative risk is considerably higher than 5 , and it means that the examined effect is almost completely caused by impacts exerted by intense in-plant noise with etiological fraction (EF) varying from 81 to $100 \%$.

Table 3

Prevalence of signs showing noise impacts on hearing organs in workers employed at petrochemical production

\begin{tabular}{|c|c|c|c|}
\hline \multirow{2}{*}{$\begin{array}{c}\text { Working } \\
\text { period, } \\
\text { years }\end{array}$} & \multicolumn{3}{|c|}{$\begin{array}{c}\text { Number of people with detected signs } \\
\text { of noise impacts, } \%\end{array}$} \\
\hline & $\begin{array}{l}\text { Pumps and } \\
\text { compressors } \\
\text { operators }\end{array}$ & $\begin{array}{c}\text { Processing } \\
\text { equipment } \\
\text { operators }\end{array}$ & $\begin{array}{l}\text { SI and } \mathrm{AE} \\
\text { mechanics } \\
\text { (control) }\end{array}$ \\
\hline$<10$ & $* 19,7 \pm 2,6$ & $2,9 \pm 1,3$ & $0,8 \pm 0,8$ \\
\hline $10-19$ & $* 22,3 \pm 3,0$ & $\begin{array}{c}* 14,4 \pm \\
2,6\end{array}$ & $2,3 \pm 1,3$ \\
\hline $\begin{array}{c}20 \text { and } \\
\text { more }\end{array}$ & $* 29,4 \pm 2,6$ & $\begin{array}{c}* 23,6 \pm \\
2,4\end{array}$ & $1,4 \pm 0,7$ \\
\hline Totally & $* 24,7 \pm 1,6$ & $\begin{array}{c}* 15,7 \pm \\
1,4\end{array}$ & $1,5 \pm 0,5$ \\
\hline
\end{tabular}

Note: Discrepancies are statistically authentic: $* p<0.001$

Table 4

Relative risk (RR) causing occurrence of signs showing noise impacts on hearing organs in occupational groups

\begin{tabular}{|c|c|c|}
\hline \multirow{2}{*}{$\begin{array}{c}\text { Working pe- } \\
\text { riod, years }\end{array}$} & $\begin{array}{c}\text { Relative risk (RR) causing occur- } \\
\text { rence of signs showing noise im- } \\
\text { pacts on hearing organs in occupa- } \\
\text { tional groups }\end{array}$ \\
\cline { 2 - 3 } & $\begin{array}{c}\text { Pumps and } \\
\text { compressors } \\
\text { operators }\end{array}$ & $\begin{array}{c}\text { Processing } \\
\text { equipment oper- } \\
\text { ators }\end{array}$ \\
\hline$<10$ & 24,6 & 3,6 \\
\hline $10-19$ & 9,7 & 6,3 \\
\hline 20 and more & 21,0 & 16,9 \\
\hline Totally & 16,5 & 10,5 \\
\hline
\end{tabular}

So, clinical-hygienic research revealed that increased levels of in-plant noise impacts at the examined productions caused risk of occupational diseases evolvement in hearing organs. 
The conducted research gave ground for implementation of a set of activities aimed at noise reduction; these activities included noise reduction means at sources of its occurrence and means of protection from it on the way it spreads.

We can name such most efficient collective protectors against noise as application of low-noise technological equipment, acoustic means application (sound insulation, sound absorption etc.), remote control, as well as rational labor and rest regime.

But bearing in mind that collective protectors can't always reduce noise volume at working places, we think it's necessary to apply individual protectors of hearing organs (ear phones, ear plugs etc.).

Medical care and occupational rehabilitation of people with occupational hearing loss also play a very important role in sensory hearing loss prevention. Qualitative and regular medical supervision allowing for noise volume and working period at petrochemical production will help to 1) increase a time period during which signs showing noise impact exerted on hearing organs transfer into actual hearing loss; 2) reduce occupational losses among workers under noise volumes which are higher than maximum permissible one and to prolong productive working period.

\section{References}

1. Adeniniskaya E.E., Gorblyanskaya Yu.Yu., Khoruzhaya O.T. Izuchenie klinicheskoi effektivnosti meditsinskogo nablyudeniya za rabotnikami, zanyatymi v usloviyakh vozdeistviya shuma [Studying clinical efficiency of medical observation on workers functioning under noise exposure]. Sanitarnyi vrach, 2014, no. 7, pp. 22-28 (in Russian).

2. Adeniniskaya E.E., Pankova V.B. Proekt federal'nykh klinicheskikh rekomendatsii po diagnostike, lecheniyu i profilaktike poteri slukha, vyzvannoi shumom: garmonizirovannaya klassifikatsiya stepeni tugoukhosti [The draft of Federal clinical practice guidelines for diagnosis, treatment and prevention of noise induced hearing loss: how we made it]. Meditsina truda i promyshlennaya ekologiya, 2015, no. 9, pp. 19-20 (in Russian).

3. Zinkin V.N., Sheshegov P.M., Chistov S.D. Klinicheskie aspekty professional'noi sensonevral'noi tugoukhosti akusticheskogo geneza [The clinical aspects of occupational sensorineural impairment of hearing of the acoustic origin]. Vestnik otoringologii, 2015, no. 6, pp. 65-70 (in Russian).

4. Izmerov N.F., Denisov E.I., Morozova T.V. Okhrana zdorov'ya rabotnikov: garmonizatsiya terminologii, zakonodatel'stva i praktiki s mezhdunarodnymi standartami [Health at work: Harmonization of terminology, laws and practice with international standards]. Meditsina truda i promyshlennaya ekologiya, 2012, no. 8, pp. 1-7 (in Russian).

5. Ikonnikova I.V., Boiko I.V., Klitsenko O.A. Otsenka faktorov riska razvitiya sensonevral'noi tugoukhosti u rabotnikov gazotransportnogo predpriyatiya Krainego Severa [Evaluation of risk factors for neurosensory deafness in workers engaged into gas transport enterprise in Far North]. Meditsina truda i promyshlennaya ekologiya, 2015, no. 2, pp. $26-29$ (in Russian).

6. Karamova L.M., Karimova L.K., Basharova G.R. Professional'nyi risk dlya zdorov'ya rabotnikov khimicheskikh i neftekhimicheskikh proizvodstv [Occupational health risk for workers employed at chemical and petrochemical production]. Ufa, 2006, 306 p. (in Russian).

7. Mavrina L.N., Karimova L.K., Beigul N.A. Profilakticheskie mery po obespecheniyu bezopasnykh uslovii truda $\mathrm{v}$ proizvodstvakh etilbenzola-stirola [Preventive measures aimed at providing safe working conditions at ethylbenzene-styrene production]. Aktual'nye napravleniya nauchnykh issledovanii: ot teorii k praktike: materialy VII Mezhdunarodnoi naucho-prakticheskoi konferentsii [Modern trends in scientific research: from theory to practice: materials of VII International theoretical and practical conference]. Cheboksary, Interaktiv plyus Publ., 2016, vol. 1, no. 7, pp. 77-78 (in Russian).

8. MR 14-1/10/2-3508. Diagnostika, ekspertiza trudosposobnosti i profilaktika professional'noi sensonevral'noi tugoukhosti: Metodicheskie rekomendatsii 14-1/10/2-3508 [Diagnostics, working capaci- 
ty examination and prevention of occupational sensorineural hearing loss: methodical guidelines 141/10/2-3508]. Moscow, 2012, 28 p. Available at: http: //docs.cntd.ru/document/902382564 (28.09.2016). (in Russian).

9. O sostoyanii sanitarno-epidemiologicheskogo blagopoluchiya naseleniya v Rossiiskoi Federatsii v 2013 godu: Gosudarstvennyi doklad [On sanitary and epidemiologic welfare of the population in the Russian Federation in 2013: State report]. Moscow, Federal'naya sluzhba po nadzoru v sfere zashchity prav potrebitelei i blagopoluchiya, 2014, 191 p. (in Russian).

10. Pankova V.B., Tavartkiladze G.A., Mukhamedova G.R. Professional'naya tugoukhost': novye podkhody $\mathrm{k}$ diagnostike, ekspertize trudosposobnosti i reabilitatsii [Occupational hearing loss: new approach to diagnostic, labour capacity examination and rehabilitation]. Meditsina ekstremal'nykh situatsii, 2013, no. 1, pp. 25-29 (in Russian).

11. Professional'naya patologiya: natsional'noe rukovodstvo [Occupational pathology: national guide]. In: N.F. Izmerov, ed. Moscow, TEOTAR.-Media Publ., 2011, 784 p. (in Russian).

12. Preobrazhenskaya E.A., Yatsyna I.V., Sineva E.L., Fedina I.N., Lipatova L.V. Retrospektivnyi analiz i zakonomernosti formirovaniya professional'noi tugoukhosti v sovremennykh usloviyakh [Retrospective analysis and principles of occupational deafness formation nowadays]. Meditsina truda $i$ promyshlennaya ekologiya, 2015, no. 10, pp. 31-35 (in Russian).

13. Pankova V.B., Sineva E.L., Tavartkiladze G.A., Fedina I.N., Preobrazhenskaya E.A., Mukhamedova G.R. Sovremennye aspekty garmonizatsii klassifikatsii professional'noi tugoukhosti [Current aspects of harmonization of classification of occupational hearing loss]. Vestnik otorinolaringologii, 2013, no. 2, pp. 27-30 (in Russian).

14. Sostoyanie professional'noi zabolevaemosti v Rossiiskoi Federatsii v 2012 godu [Occupational morbidity in the Russian Federation in 2012]. Informatsionnyi sbornik statisticheskikh $i$ analiticheskikh materialov [Collected statistical and analytical materials]. Moscow, Federal'nyi tsentr gigieny i epidemiologii Rospotrebnadzora Publ., 2013, 48 p. (in Russian).

15. Kharitonova O.I., Poteryaeva E.L., Kruglikova N.V. Professional'naya neirosensornaya tugoukhost' u chlenov ekipazhei vozdushnykh sudov grazhdanskoi aviatsii [Occupational neurosensory deafness in civil aircraft crew members]. Meditsina truda i promyshlennaya ekologiya, 2015, no. 6, pp. 1214 (in Russian).

16. Andreeva-Galanina E.Ts., Alekseev S.V. [et al.] Shum i shumovaya bolezn' [Noise and noise disease]. Leningrad, Meditsina Publ., 1972, 303 p. (in Russian).

17. Augustynka D. Zagrozenia halasem na stanowiskach pracy w polsce innych pantstwach uni Europejskiej. Medycyna Pracy, 2012, vol. 63, no. 6, pp. 689-700.

18. Biocca M. Risk Communication and the Precautionary Principle. International Journal of Occupational Medicine and Environmental Health, 2004, vol. 17, no. 1, pp. 197-201.

19. Choi Y.-H., Kim K. Noise-Induced Hearing Loss in Korean Workers: Co-Exposure to Organic Solvents and Heavy Metals in Nationwide Industries. PLoS ONE, 2014, vol. 9, no. 5, pp. 214-287. DOI: 10.1371/journal.pone.0097538

20. Covello V.T. Risk Communication and Message Mapping: A New Tool for Communicating Effectively in Public Health Emergencies and Disasters. Journal of Emergency Management, 2006, vol. 4, no. 3, pp. 25-40.

21. Leensen M.C.J., Duivenbooden J.C.van, Dreschler W.A. A retrospective analysis of noiseinduced hearing loss in the Dutch construction industry. International Archives of Occupational and Environmental Health, 2004, vol. 84, no. 5, pp. 577-590. DOI: 10.1007/s00420-010-0606-3.

22. Leeves G.D., Herbert R.D. Economic and environmental impacts of pollution control in a system of envi-ronment and economic interdependence. Chaos, Solitons \& Fractals, 2002, vol. 13, no. 4, pp. 693-700. DOI: 10.1016/S0960-0779 (01) 00003-0.

23. Noise-Induced Hearing Loss (NIHL) in Great Britain. Health and Stafety Executive. Available at: http: //www.hse.gov.uk/Statistics/causdis/deafness/index.htm (10.09.2016).

24. Arve Lie, Marit Skogstad, Håkon A. Johannessen, Tore Tynes, Ingrid Sivesind Mehlum, Karl-Christian Nordby, Bo Engdahl, Kristian Tambs. Occupational noise exposure and hearing: a systematic review. International Archives of Occupational and Environmental Health, 2016, vol. 89, no. 3, pp. 351-372. DOI: 10.1007/s00420-015-1083-5. 
25. Tsutsumi A., Kayaba K., Kario K., Ishikawa S. Prospective study on occupational stress and risk of stroke. Arch. Internal Med, 2009, vol. 169, no. 1, pp. 56-63.

Volgareva A.D., Karimova L.K., Mavrina L.N., Gimaeva Z.F., Beigul N.A. In-plant noise as occupational risk factor at petrochemical plants. Health Risk Analysis, 2017, no. 1, pp. 110-117. DOI: 10.21668/health.risk/2017.1.13.eng

Received: 28.11.2016

Accepted: 26.02.2017

Published: 30.03 .2017 